\title{
High School Student Career Plans: Concepts and Reality
}

\author{
Tri Cahyono ${ }^{1 *}$
}

\author{
${ }^{1}$ Guidance and Counseling Department, Universitas Borneo Tarakan \\ Corresponding Author*Email:tricahyonoubt@gmail.com
}

\begin{abstract}
The pointing according to study interest is one of the characteristics of education at the high school level. One of the goals of this majors is to place students in fields that match their interests and talents. By tracing the interests and talents of students, they can reach peak competencies, namely becoming experts and professionals in the field they are engaged in. This study focuses on evaluating the process of implementing specialization services at secondary schools in the province of North Kalimantan, Indonesia. The result of this research is that there are four obstacles faced by counselors in service, namely 1) the collaboration between the counselor, homeroom teacher, parents, and other elements is still lacking; 2) there is no sufficient track record for SMA counselors to trace the talents/interests of students at the previous school level; 3) parental support for the development of student talents interests is lacking; 4) students do not have enough stability in choosing the right career choice for themselves. Suggestions are given to schools and parents to get together as early as possible to find out the direction of the development of students' talents and interests. Detecting students' talents and interests will have a major impact on the direction of children's competence in school. The earlier the competence is trained, the higher the achievement will be.
\end{abstract}

\section{Keywords: Majors Services, Evaluation}

\section{INTRODUCTION}

One of the peculiarities of guidance and counseling services in the K13 curriculum is Career Specialization Services' absence. The uniqueness of this service is the opportunity for students to develop skills by the principles of interest. Students' interest is a process of selection and decision by students in the field of expertise based on understanding their potential and opportunities. In this context, guidance and counseling help students to understand themselves, accept themselves, direct themselves, make self-decisions, realize their decisions responsibly (Raharjeng, 2014)

Career Specialization Services are guidance and counseling services provided to accommodate students' choice of interests, talents, and abilities with the orientation of concentration, expansion, and deepening of subjects or vocational content.

(Kemendikbud, 2016) At the high school level, Career Specialization Services are based on the selection and determination of subject groups or deepening interests based on self-potential such as general intelligence, talent, interests, and ideals.
Erth Support and opportunities organized by the education unit.

At the high school level, the interest of the group of subjects and the choice of subjects is an effort to help students select and deepen the subjects that are followed in the education unit. Understanding and choosing the direction of career development to prepare them to choose further education to go to college following the general basic skills, talents, interests, and tendencies of each student's choice. Efforts to optimize students' potential demand good collaboration between subject teachers, teachers, counselors, principals, and parents/guardians, such as material deepening services conducted by teachers of subjects is one form of enrichment of subjects (Kemendikbud, 2014)

Career Specialization Services' maintenance is not limited to selecting and assigning students in areas of interest or according to the talents that students already have, but in the Career Specialization Services, further steps such as mentoring, development, channeling, evaluation, and follow-up. Student interest is an effort to advocate and facilitate students' development to 
actively develop their potential to have religious, spiritual strength, self-control, personality, intelligence, noble morals, and the skills necessary for themselves, society, nation, and country to achieve optimal development.

Aspects that need to be considered in conducting the selection and determination of high school and vocational students' interest can include learning achievement, non-academic achievement, national test scores, statements of interest of students, ideals, and parental attention (Bimbingan \& Indonesia, 2007). Thus, it will allow students to develop abilities, talents, and interests more broadly and openly, following the principles of individual differences. It allows students to develop over achievement,i.e., students who have mastery above the standards set in both pieces of knowledge, attitude, and skills.

On the other hand, the application of Career Specialization Services carried out by school counselors does not all work optimally. The obstacles are often found in the implementation of the service. For example, parents force their children to enter a particular interest group (Dewi \& Nuryono, 2014). Another obstacle is a lack of understanding of counseling guidance teachers on academic interests, relatively short implementation times, and discrepancies between school decisions and students' and their parents' wishes. The last obstacle is placement results that did not receive parents' support (Raharjeng, 2014).

The discovery of these obstacles led researchers to observe two schools in North Kalimantan province. Based on the initial observations at the two schools, it is known as follows: 1) not all counselors have participated in K13 training in the field of guidance and counseling, 2) counselors independently learn the concept of Career Specialization Services through social networks and modules that circulate widely on social media and 3) not all concepts of placement services can be implemented optimally. The above exposures are the basis for researchers to learn more about Career Specialization Services' application, especially in school backgrounds that have implemented the 2013 curriculum.

\section{METHODOLOGY}

This research uses case study research methods by focusing on the constraints in applying Career Specialization Services conducted by counselors in high school in North Kalimantan province, the curriculum 2013. The data source in this study is one of the schools that is the pioneer school of curriculum 2013. Data collection methods are carried out with documentation, interviews, and open polls.

Broadly the stages of the study of this case consist of 1) Selection of Themes, Topics, and Cases; 2) Reading of Literature; 3) Formulation of Research Focus and Problems; 4) Data Collection; 5) Data Enhancement; 6) Data Analysis; 7) Theorized Dialogue; 8) Triangulation (Affirmability); 9) Conclusion of Research Results.

\section{RESULTS AND DISCUSSIONS}

In this study, researchers divided the research based on Career Specialization Services' stage following the SMA-SMK Interest Guidelines (Kemendikbud, 2016), consisting of six stages.

1. Providing Interest Information

2. Data Collection

3. Identification and Determination of Interest

4. Adjustment and Mentoring

5. Monitoring and Follow-up

The results of this study are stacked based on differences in concept and reality. In general, the results of this study can be seen in the following table. 


\begin{tabular}{|c|c|c|c|c|}
\hline $\mathbf{N}$ & Stage & Concept & Reality & $\begin{array}{c}\text { Discussion } \\
\end{array}$ \\
\hline \multirow[t]{3}{*}{1} & \multirow[t]{3}{*}{$\begin{array}{l}\text { Interest } \\
\text { Information }\end{array}$} & $\begin{array}{l}\text { A. Performed the first time they entered } \\
\text { the school (along with the admission of } \\
\text { new students (PPDB) or received } \\
\text { (beginning of study orientation period } \\
\text { (MOS)). }\end{array}$ & $\begin{array}{l}\text { Interest information is done when } \\
\text { high school students accepted } \\
\text { (beginning of study orientation } \\
\text { period (MOS) }\end{array}$ & \multirow{3}{*}{$\begin{array}{l}\text { The implementation of socialization } \\
\text { on interest information conducted } \\
\text { when high school students are } \\
\text { declared accepted (the beginning of } \\
\text { the study orientation period (MOS) } \\
\text { is considered less maximal because } \\
\text { it is not accompanied by training to } \\
\text { choose the interest of the group of } \\
\text { subjects, cross-subject interest, and } \\
\text { interest in deepening the subject } \\
\text { matter. By conducting the training, } \\
\text { students can determine the choice of } \\
\text { interest in the group of subjects, } \\
\text { cross-subject interest, and interest in } \\
\text { deepening the subject matter } \\
\text { appropriately }\end{array}$} \\
\hline & & $\begin{array}{l}\text { B. Prospective students are given more } \\
\text { information about the choice of interest in } \\
\text { the group of subjects, cross subject } \\
\text { interest, and interest in deepening the } \\
\text { subject matter in high school }\end{array}$ & $\begin{array}{l}\text { Information provided about interest } \\
\text { options for groups of subjects, } \\
\text { cross-subject interests, and interests } \\
\text { deepening of subject matter in high } \\
\text { school }\end{array}$ & \\
\hline & & $\begin{array}{l}\text { C. From the time of admission of new } \\
\text { students (PPDB) or after being declared } \\
\text { accepted (beginning of the study } \\
\text { orientation period (MOS), students can } \\
\text { select a group of subjects, a selection of } \\
\text { cross-interest subjects, and deepening of } \\
\text { subject matter according to their interests }\end{array}$ & $\begin{array}{l}\text { Students have not been able to fully } \\
\text { understand the choice of cross- } \\
\text { interest subjects, and deepen the } \\
\text { subject matter according to their } \\
\text { interests }\end{array}$ & \\
\hline \multirow[t]{2}{*}{2} & \multirow[t]{2}{*}{ Data Colletion } & $\begin{array}{l}\text { A. Can be used test techniques (talent } \\
\text { interest tests) as well as non-test } \\
\text { techniques (documentation, talent interest } \\
\text { polls, interviews, observations, etc.) }\end{array}$ & $\begin{array}{l}\text { Data collection using non-test } \\
\text { techniques with two types of } \\
\text { methods data collection i.e. talent } \\
\text { interest polls and interviews }\end{array}$ & \multirow{2}{*}{$\begin{array}{l}\text { Data collection with various } \\
\text { instruments to know the } \\
\text { talents/interests of students is well } \\
\text { implemented and can be } \\
\text { preliminary information for } \\
\text { counselors to establish the interest } \\
\text { of the group of subjects, the choice } \\
\text { of cross-interest subiects, and the } \\
\text { deepening of the subject matter }\end{array}$} \\
\hline & & $\begin{array}{l}\text { B. The data that can be obtained is } \\
\text { analyzed and used as the basis for } \\
\text { determining the interest of students. }\end{array}$ & $\begin{array}{l}\text { The data that can be obtained is } \\
\text { analyzed and used as the basis for } \\
\text { determining the interest of students. }\end{array}$ & \\
\hline 3 & $\begin{array}{l}\text { Identification } \\
\text { and } \\
\text { Determination } \\
\text { of Interests }\end{array}$ & $\begin{array}{l}\text { A. Disseminate questionnaires to net } \\
\text { students a choice of subjects, cross- } \\
\text { subjects, and deepening subjects. } \\
\text { In the selection of interest students are } \\
\text { required to consider their potential, } \\
\text { learning achievements and non-academic } \\
\text { achievements that have been obtained, } \\
\text { ideals, learning interests and parental } \\
\text { attention. }\end{array}$ & $\begin{array}{l}\text { Disseminate questionnaires of } \\
\text { interest options of subjects, across } \\
\text { subjects, and deepening the desired } \\
\text { subjects. } \\
\text { Students are worried and do not } \\
\text { fully understand how to know the } \\
\text { potential of learning achievements } \\
\text { and non-academic achievements } \\
\text { that have been obtained, ideals, } \\
\text { learning interests and parental } \\
\text { attention. }\end{array}$ & $\begin{array}{l}\text { Questionnaires distributed to } \\
\text { students do not represent the true } \\
\text { talents/interests of students. } \\
\text { Without sufficient insight into the } \\
\text { procedures for determining and } \\
\text { izing the choice of interest so that } \\
\text { students are almost all students feel } \\
\text { concern. }\end{array}$ \\
\hline \multirow[t]{3}{*}{4} & \multirow[t]{3}{*}{$\begin{array}{l}\text { Adjustments } \\
\text { and mentoring }\end{array}$} & $\begin{array}{l}\text { A. Students make adjustments to the } \\
\text { interest of the group of } \\
\text { subjects, cross-subject interest, and the } \\
\text { deepening interest of the selected and } \\
\text { assigned subjects }\end{array}$ & $\begin{array}{l}\text { Students make adjustments to the } \\
\text { interest of subject groups, cross- } \\
\text { subject interests, and eye deepening } \\
\text { interests selected and assigned } \\
\text { lessons }\end{array}$ & \multirow{3}{*}{$\begin{array}{l}\text { Cases of students requesting to } \\
\text { move groups of subjects often occur } \\
\text { even until the end of the school } \\
\text { year. Counsellors need to do } \\
\text { mentoring more robustly by } \\
\text { collaborating with subject teachers } \\
\text { and the class guardian. Still lack of } \\
\text { support from other school members } \\
\text { also makes it difficult for sisw to } \\
\text { have a heart-monitoring according } \\
\text { to the choice of interest of the group } \\
\text { of subjects. }\end{array}$} \\
\hline & & $\begin{array}{l}\text { B. Students/parents may consult the } \\
\text { counselor when worried, doubtful or } \\
\text { worried about his chosen interest }\end{array}$ & $\begin{array}{l}\text { Students parents' interests to consult } \\
\text { a counsellor is still low, especially } \\
\text { when worried, hesitant to or } \\
\text { worried about their chosen } \\
\text { interests }\end{array}$ & \\
\hline & & $\begin{array}{l}\text { C. Counselors conduct counseling to } \\
\text { students who need } \\
\text { alleviation related to interest adjustment }\end{array}$ & $\begin{array}{l}\text { Counselors conduct counseling to } \\
\text { students who need alleviation } \\
\text { related to interest adjustments }\end{array}$ & \\
\hline \multirow[t]{2}{*}{5} & \multirow[t]{2}{*}{$\begin{array}{l}\text { Monitoring and } \\
\text { Follow-Up }\end{array}$} & $\begin{array}{l}\text { A. BK Teachers/Counselors, Subject } \\
\text { Teachers, and Classroom Teachers } \\
\text { collaborate to monitor the activities of } \\
\text { students as a whole in undergoing } \\
\text { educational programs attended by students }\end{array}$ & $\begin{array}{l}\text { BK Teachers/Counselors and } \\
\text { Teacher Parents collaborate to } \\
\text { monitor the activities of students as } \\
\text { a whole in undergoing educational } \\
\text { programs followed by students }\end{array}$ & \multirow{2}{*}{$\begin{array}{l}\text { Collaboration between counselors, } \\
\text { subject teachers and parents needs } \\
\text { to be supported by the principal to } \\
\text { maintain continuity. Monitoring } \\
\text { will not be able to run maximum if } \\
\text { only done by counselors only. } \\
\text { Because the follow-up to the } \\
\text { interest option applies until the } \\
\text { student graduates from high school. }\end{array}$} \\
\hline & & $\begin{array}{l}\text { B. The development and various problems } \\
\text { of students that occur in the interest of the } \\
\text { group of subjects, crosssubject interest, } \\
\text { and interest in deepening subjects are } \\
\text { followed up through appropriate sara } \\
\text { guidance and counseling services } \\
\text { (classical group guidance, courseling } \\
\text { individuals/groups, case studies, case } \\
\text { conferences, case outsourcing, etc.) }\end{array}$ & $\begin{array}{l}\text { Follow-up on students' concerns } \\
\text { that occur in the interest of subject } \\
\text { groups, cross-subject interest, and } \\
\text { interest in deepening low subjects. }\end{array}$ & \\
\hline
\end{tabular}




\section{CONCLUSION}

Career Specialization

Services' implementation is a collaborative effort between counselors, parents, subject teachers, parents, and other school members. Without collaboration from various elements, the school Career Specialization Services students into the subjects, cross-subject interest, and interest in deepening subjects could not go well.

The results of the research that has been done show that the four most basic constraints occur in the implementation of Career Specialization Services:

1. A collaboration between counselors, parents, parents, and other elements is still lacking, causing various deadlocks in adjusting interest options.

2. There is not enough track record for high school counselors to students' talents in junior high school and elementary school. Junior high school counselors need also to develop Career Specialization Services for the convenience of their students' interest choices.

3. The parental support for the development of students' talents/interests is very lacking, so the child cannot find the real potential that he or she has.

4. Students do not have enough stability in choosing the right career choice for themselves.

There is not enough support from various parties as long as they are at the elementary and junior high school levels.

More clearly, the constraints of Career Specialization Services' implementation can be seen in the following image.

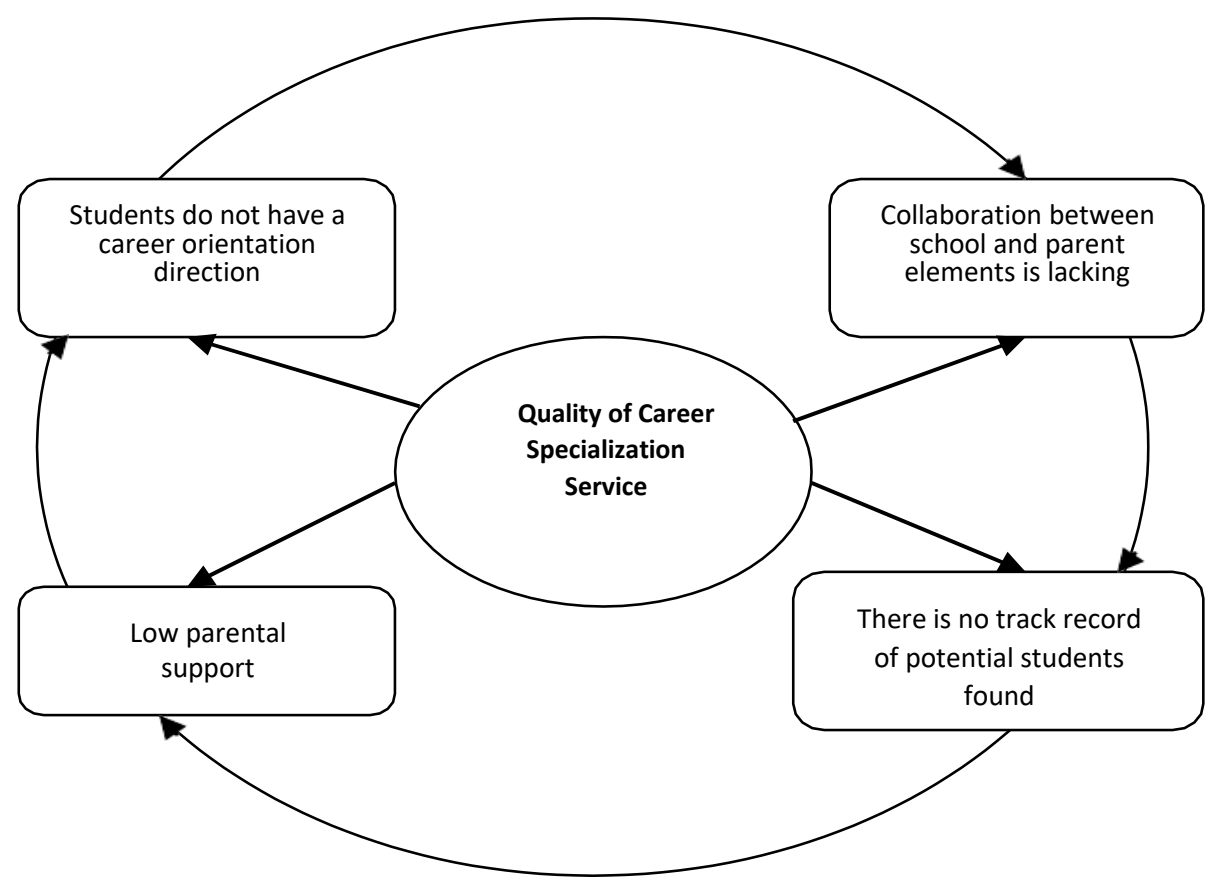

Image of the constraints of the implementation of Career Specialization Service

Advice is made to both the school and parents. They can collaborate to know the direction of the development of students' talents and interests. The detection of students' talents and interests will significantly impact the direction of competence of children in school. The earlier the competency is trained, the higher the achievement.

There needs to be greater collaboration between school levels so that there is no missinglink track record. Counselors, teachers, and parents 
need to understand the importance of placing students according to their talents/interests or competencies in each learner's field of expertise.

\section{REFERENCES}

[1] Bimbingan, A., \& Indonesia, K. (2007). Rambu-Rambu Penyelenggaraan Bimbingan dan Konseling dalam Jalur Pendidikan Formal (Naskah Akademik). Bandung: ABKIN.

[2] Dewi, F. Y., \& Nuryono, W. (2014). Survei Tentang Hambatan-Hambatan Selama Proses Peminatan (Dalam Konteks Bk) Berdasarkan Kurikulum 2013 Bagi Siswa Di Sma Negeri Se-Kota Surabaya. Jurnal BK.

[3] Kemendikbud. (2014). Materi Pelatihan Guru Implementasi Kurikulum 2013. Badan Pengembangan Sumber Daya Manusia Pendidikan Dan Kebudayaan Dan Penjaminan Mutu Pendidikan Kementerian Pendidikan Dan Kebudayaan.

[4] Kemendikbud, D. G. dan T. K. (2016). Panduan Operasional Penyelenggaraan Bimbingan dan Konseling Sekolah Menengah Kejuruan. Academia.Edu.

[5] Raharjeng, R. S. (2014). Implementasi Kurikulum 2013 Bimbingan Dan Konseling Dalam Pelaksanaan Layanan Peminatan Peserta Didik Sma Negeri 2 Lamongan Tahun Ajaran 2013/2014 Implementation. Jurnal BK Unesa. 